\title{
Analisis Efektivitas Sistem Pengendalian Internal Dalam Mengatasi Kredit Macet Dengan Menerapkan Prinsip "Pang Pade Payu" Pada BUMDES Sidi Amerta
}

\author{
Made Erawati ${ }^{1}$, Anantawikrama Tungga Atmadja ${ }^{2}$ \\ 1,2 Prodi S1 Akuntansi, Universitas Pendidikan Ganesha, \\ Singaraja, Indonesia \\ e-mail : ${ }^{1}$ erawatiii98@gmail.com, ${ }^{2} \mid$ anantawikrama t atmadja@undiksha.ac.id\}
}

\begin{abstract}
Abstrak
BUMDes Sidi Amerta merupakan lembaga sektor formal dengan usaha desa yang dikelola oleh Desa secara bersama dan berbadan hukum, salah satu operasionalnya yaitu usaha simpan pinjam. Penelitian ini bertujuan untuk mengetahui (1) Bagaimana sistem pengendalian internal yang diterapkan Badan Usaha Milik Desa Sidi Amerta Sangsit dalam menghadapi kredit macet, (2) Bagaimana penerapan prinsip "pang pade payu" untuk menyelesaikan kredit macet pada BUMDes Sidi Amerta. Dalam penelitian ini menggunakan metode deskritif dengan pendekatan kualitatif. Metode pengempulan data diperoleh melalui metode observasi, metode wawancara, dan dengan metode dokumentasi yang dilakukan di BUMDes Sidi Amerta. Pengolahan data yang telah terkumpul kemudian dianalisis melalui reduksi data, penyajian data dan penarikan kesimpulan. Hasil penelitian menunjukkan bahwa pelaksanaan (1) sistem pengendalian internal di BUMDes Sidi Amerta cukup bagus dengan pengawasan yang dilakukan berkala sudah berjalan dengan efektif, namun kurangnya pengetahuan pengurus di bidang akuntansi memungkinkan adanya kecurangan; (2) Efektivitas penerapan prinsip "pang pade payu" untuk nasabah kredit macet tergolong cukup efektif, karena menggunakan pendekatan secara kekeluargaan yang membuat para nasabah mendapat keringanan dalam membayar kewajibannya dengan tidak bersifat memaksa sehingga meningkatkan kesadaran nasabah untuk membayar kewajibannya; (3) Saran tindak atau upaya yang dilakukan yaitu lebih bisa selektif dalam pemberian kredit sesuai dengan kemampuan nasabah pencari kredit tersebut.
\end{abstract}

Kata Kunci: BUMDes Sidi Amerta, Kredit macet, Prinsip "pang pade payu"

\begin{abstract}
BUMDes Sidi Amerta is an official institution with a village managed by a joint and legal entity village, one of the operations of which is a savings and loan business. This study was intended to find out (1) How the internal control system applied by the Sidi Amerta Village Business Entity in implementing bad credit, (2) How to apply the "pang pade payu" principle to get bad credit at the Sidi Amerta BUMDes. In this study using a descriptive method with a qualitatitive approach. The data collection method was obtained through the observation method, the interview method, and the documentation method conducted at BUMDes Sidi Amerta. The data processing that has been collected is then completed through data reduction, data presentation and making conclusion. The results showed that the implementation of (1) the internal control system at BUMDes Sidii Amerta was quite good with supervision carried out effectively, but the management's knowledge in the field of accounting allowed for fraud; (2) The effectiveness of the application of the principle of "pang pade payu" for bad loans is quite effective, because it uses a family that makes the recipients get relief in paying for their needs without protection increasing the importance of care to pay for their needs; (3) Suggestions for follow-up actions carried out are more selective in granting loans in accordance with the ability of the credit assistance.
\end{abstract}

Keywords : BUMDes Sidi Amerta, bad credits, concept of "pang pade payu" 


\section{Pendahuluan}

Pemerintah Indonesia telah menerapkan berbagai macam program pemberdayaan ekonomi dan meningkatkan jaminan sosial pedesaan. Khususnya untuk Pemerintah Provinsi Bali yang telah mendirikan sebuah program untuk mengentaskan kemiskinan yang ada di daerah Bali, yang diberi nama Program Gerbang Sadu Mandara bertujuan untuk membantu perkembangan pembangunan desa yang dimana dananya dikeluarkan melalui APBD Bali. Menurut Peraturan Gubernur Bali Lembaga yang dapat digunakan untuk menyalurkan dana operasional Gerbang Sadu Mandara yaitu Badan Usaha Milik Desa (BUMDes). BUMDes merupakan pilar kegiatan ekonomi didesa yang berfungsi sebagai lembaga sosial dan komersial..

Salah satu desa yang mendapatkan dana hibah program GSM ini adalah Desa Sangsit yang mana dana tersebut dikelola oleh BUMDes Sangsit yang bernama BUMDes "Sidi Amerta". BUMDes Sidi Amerta merupakan lembaga sektor formal dengan usaha desa yang dikelola oleh Desa, yang dikelola secara bersama dan berbadan hukum. Permodalan BUMDes Sidi Amerta bersumber dari dana GSM Rp. 1.020.000.000, Namun biaya untuk operasional dari BUMDes Sidi Amerta sebesar Rp. 934.300.000, sisanya yaitu Rp 85.700.000 digunakan untuk biaya gedung BUMDes Sidi Amerta. Dana yang didapatkan dari Program Gerbang Sadu Mandara dalam peraturan Gubernur Bali No 52 Tahun 2013, digunakan salah satunya untuk usaha simpan pinjam rakyat. Berdasarkan yang termuat dalam website BUMDes Sangsit (http://bumdessangsit.blogspot.com), dana sebesar Rp. 369.500.000 digunakan untuk pinjaman Rumah Tangga Miskin (RTM) dan pinjaman non Rumah Tangga Miskin. Besarnya pinjaman yang diberikan untuk RTM yaitu sebesar Rp. 500.000 atau lebih sesuai dengan usaha ekonominya dengan suku Bunga $1 \%$ menetap tanpa dipungut biaya administrasi. Sedangkan untuk yang non RTM dana yang dapat dipinjamkan yaitu sebesar Rp. 2.000.000 atau lebih sesuai dengan fisibelitas usahanya. Suku bunga yang dikenakan yaitu sebesar 1,5\% menetap ditambahkan dengan biaya sebesar 1 kali bunga bulanan.

Menurut Undang-undang (UU) Nomor 6 Tahun 2014 tentang Desa (Pasal 1 ayat 6) menjelaskan perihal keberadaan BUM Desa yang diartikan sebagai Badan Usaha yang seluruh atau sebagian besar modalnya dimiliki oleh Desa melalui penyertaan secara langsung yang mana modal tersebut berasal dari kekayaan Desa yang dipisahkan guna mengelola, jasa pelayanan, dan usaha lainnya untuk sebesar-besarnya kesejahteraan masyarakat desa. Adapun tujuan BUMDes dalam Peraturan Menteri Dalam Negeri Nomor 39 Tahun 2010, yaitu mengoptimalkan pengelolaan aset-aset desa yang ada, memajukan perekonomian desa, serta meningkatkan kesejahteraan masyarakat desa. Salah satu usaha yang dimiliki oleh BUMDes adalah pemberian kredit, kredit merupakan pengalihan kepemilikan asset dari badan usaha kepada perorangan yang merupakan dana dari pihak pemilik dana kepada pihak yang memerlukan dana (Ismail, 2013). Masalah yang sering terjadi yaitu kredit macet yang diakibatkan karena nasabah tidak bisa membayar kewajiban kepada BUMDes dalam jangka waktu yang telah ditentukan. Menurut Kasmir (2012) mengatakan bahwa sepandainya apa pun kredit dalam menganalisis setiap permohonan kredit, kemungkinan kredit tersebut macet pasti ada, hal ini disebabkan oleh dua unsur sebagai berikut: (1) Dari pihak perbankan, artinya dalam melakukan analisisnya, pihak analsis kurang teliti sehingga apa yang seharusnya terjadi, tidak diprediksi sebelumnya. Dapat pula terjadi akibat kolusi dari pihak analisis kredit dengan pihak debitur sehingga dalam analisnya dilakukan secara subjektif; dan (2) Dari pihak nasabah kemacetan kredit dapat dilakukan akibat dua hal yaitu: (a) Adanya unsur kesengajaan., (b) Adanya unsur tidak sengaja, artinya si debitur mau membayar, tetapi tidak mampu, seperti kredit yang dibiayai mengalami musibah. Ada pula kecurangan yang terjadi di BUMDes mengakibatkan usaha BUMDes tidak berjalan baik, dan bisa mengakibatkan kredit macet dalam usaha pemberian kredit. Oleh karena itu, perlunya Sistem pengendalian internal dalam menjalankan operasi di BUMDes. Menurut Krismiaji (2010:218) Pengendalian Internal (Internal Control) adalah rencana organisasi dan metode yang digunakan untuk menjaga atau melindungi aktiva dan menghasilkan informasi yang akurat dan dapat dipercaya. 
Adanya kasus penggelapan dana program GSM yang dilakukan oleh mantan ketua BUMDes sehingga pelaksanaan usaha simpan pinjam tersebut mengalami kendala. Hal ini terjadi karena ketidakefektifan dalam sistem pengendalian internal di usaha simpan pinjam BUMDes. Lemahnya sistem pengendalian internal pada BUMDes Sidi Amerta Desa Sangsit yang melibatkan pihak pengurus BUMDes Sidi Amerta kurang memiliki pengetahuan keahlian khusus dibidang akuntansi sehingga pengurus tidak ahli dalam bidangnya, sehingga mengalami kredi macet. Salah satu masalah lainnya adalah adanya pihak nasabah melakukan pinjaman namun tidak ada jaminan apapun yang lebih banyak dibandingkan dengan nasabah dengan menggunakan jaminan bagi Non RTM (rumah tangga miskin). Sehingga muncul ketidaksadaran atau kemauan untuk membayar kredit yang semakin meningkat, karena kesalahan persepsi dari beberapa nasabah/masyarakat yang menganggap dana yang diberikan adalah bantuan cuma-cuma dari pemerintah, bukannya pinjaman karena syarat pinjam mudah yaitu hanya dengan menunjukkan surat keterangan tidak mampu, KTP, dan KK dengan tanpa menanyakan kegunaan dari dana tersebut. Hal ini yang mengakibatkan munculnya kredit macet di BUMdes karena nasabah mengira bahwa dana yang mereka pinjam tersebut merupakan bantuan tunai langsung dari Pemerintah dan bukan pinjaman dari BUMdes itu sendiri. Banyaknya nasabah yang melakukan pinjaman tanpa anggunan apapun atau tanpa jaminan lebih banyak daripada jumlah nasabah yang melakukan pinjaman dengan menggunakan jaminan.

Tabel 1. Jumlah Data Nasabah Macet/Nunggak Per 31 Desember 2019. BUMDes Sidi Amerta Desa Sangsit Mulai Dari Tahun 2014 S/D 2019

\begin{tabular}{|c|c|c|c|c|c|}
\hline \multirow{2}{*}{$\begin{array}{l}\text { Asal } \\
\text { kelompok } \\
\text { Banjar } \\
\text { Dinas }\end{array}$} & \multicolumn{5}{|c|}{ Jumlah Nasabah Kredit Macet } \\
\hline & $\begin{array}{l}\text { Tahun } \\
2014\end{array}$ & $\begin{array}{l}\text { Tahun } \\
2015\end{array}$ & $\begin{array}{l}\text { Tahun } \\
2016\end{array}$ & $\begin{array}{l}\text { Tahun } \\
2017\end{array}$ & $\begin{array}{l}\text { Tahun } \\
2018\end{array}$ \\
\hline $\begin{array}{l}\text { BD. Pabean } \\
\text { Sangsit }\end{array}$ & - & 8 & 4 & 5 & 1 \\
\hline BD. Beji & 9 & 6 & 11 & 3 & 4 \\
\hline BD. Sema & 8 & 14 & 12 & 9 & 3 \\
\hline BD. Celuk & 9 & 9 & 6 & 8 & 7 \\
\hline BD. Tegal & 6 & 10 & 3 & 6 & 10 \\
\hline BD.Peken & 24 & 19 & 14 & 19 & 7 \\
\hline BD.Peken & & 3 & 3 & 3 & 1 \\
\hline $\begin{array}{l}\text { Jumlah } \\
\text { Nasabah }\end{array}$ & $\overline{56}$ & 69 & 53 & 53 & 33 \\
\hline $\begin{array}{l}\text { Jumlah } \\
\text { Pinjman }\end{array}$ & $\begin{array}{l}\text { Rp.97 } \\
\text { Juta }\end{array}$ & $\begin{array}{l}\text { Rp. } 140 \\
\text { Juta }\end{array}$ & $\begin{array}{c}\text { Rp.122, } \\
5 \text { Juta }\end{array}$ & $\begin{array}{l}132.5 \\
\text { Juta }\end{array}$ & $\begin{array}{l}88 \\
\text { Juta }\end{array}$ \\
\hline
\end{tabular}

Berdasarkan Laporan Tahun 2014 s/d 2019 BUMDes Sidhi Amerta, dapat dilihat dari tahun ke tahun jumlah nasabah semakin meningkat. Dilihat dari tahun 2014, jumlah nasabah terdapat sebanyak 56 orang. Ditahun 2015 terjadinya penambahan nasabah kredit macet berjumlah 69 orang. Sedangkan di tahun 2016 nasabah kredit macet bertambah sebanyak 53 orang, sama halnya ditahun 2016 nasabah kredit macet bertambah juga sebanyak 53 orang ditahun 2017. Semakin bertambahnya nasabah kredit macet tersebut menunjukkan bahwa para nasabah kurangnya kemauan dan kemampuan nasabah untuk membayarnya, jika hal ini terus-menerus terjadi maka akan menyebabkan terganggunya operasional dan kesehatan BUMDes Sidi Amerta Desa Sangsit.

Untuk menurunkan jumlah nasabah kredit macet, pihak pengurus BUMDes Sidi Amerta telah menerapkan sanksi yang telah disepakati kedua belah pihak. Seperti yang sudah dijelaskan oleh Ketua BUMDes Sidi Amerta Komang Agus Karmajaya. Hal ini dibuktikan dengan hasil kutipan wawancara Ketua BUMdes Sidi Amerta (Komang Agus Karmajaya,48) 
menyatakan bahwa para nasabah yang mengalami kredit macet tidak akan mendapatkan pelayanan pembuatan surat menyurat di Kantor Kepala Desa. BUMDes Sidhi Amerta membuat kesepakatan bersama dengan berkomitmen untuk mendukung BUMDes Sidi Amerta Sangsit dalam menghadapi permasalahan kredit macet dengan membuat aturanaturan yang mengikat agar nasabah merasa takut dengan aturan yang sudah disepakati bersama.

Dari penerapan sanksi Administrasi yang sudah diterapkan oleh pihak pengurus BUMDes Sidi Amerta tidak membuat efek jera bagi para nasabah yang mengalami kredit macet dan para nasabah belum adanya kesadaran untuk mau membayar kredit macet tersebut. Sehingga, BUMDes Sidi Amerta Desa Sangsit menerapkan penyelesain masalah kredit macet yaitu dengan cara menerapkan prinsip "pang pade payu". Hal ini dibuktikan dengan hasil kutipan wawancara terhadap Ketua BUMdes Sidi Amerta (Komang Agus Karmajaya,48) mengatakan bahwa:

"Alasan kenape bapak kanti ngalih pihak nasabah keumahne secara langsung nakonang masalah nike (Alasan mengapa Bapak ingin bertemu pihak nasabah kerumahnya secara langsung untuk menannyakan masalahnya), dadine pang pade jalan dari pihak nasabah jak bapak selaku pengurus bumdes secara baik-baik (agar nantinya sama-sama berjalan baik dari pihak nasabah dengan Bapak selaku pengurus bumdes), apang kedepanne kita selaku pengurus pang melah ajak ragane sane dadi nasabah(agar nantinya untuk kedepannya kita selaku pengurus sama-sama baik dengan dia sebagai nasabah, nasabah disini tidak akan berkurang lan rage ngelah rasa menyame lingkungan niki (dan kami bisa saling memiliki rasa kekeluargaan)."

Hal tersebut merupakan alternatif dari memecahkan masalah kredit macet ini yang diterapkan di BUMDes yang sering disebut dengan prinsip "pang pade payu". Prinsip "pang pade payu" ini di selenggarakan agar pelunasan kewajiban dari nasabah bisa terpenuhi dengan cara kekeluargaan oleh pihak BUMDes kepada nasabah dan tanpa adanya tindakan pemaksaan dari pihak BUMDes tersebut selama adanya etikad baik dari pihak nasabah. Maka, di akhir tahun 2017 sudah menerapkan prinsip "pang pade payu", sehingga di tahun 2018 mengurangi pertambahan nasabah kredit macet sebanyak 33 orang dalam laporan tahun 2014/2019 BUMDes Sidi Amerta.

Adapun keunikan yang membedakan penelitian ini dari penelitian sebelumnya yakni, BUMDes Sidi Amerta yang merupakan Badan usaha milik desa yang dikelola oleh Pemerintah Desa, dan berbadan hukum dan tidak adanya Sanksi adat desa melainkan hanya terdapat sanksi dari peraturan pemerintah dengan tidak dilayani administrasi suratmenyurat dikantor Kepala Desa. Namun pada BUMDes Sidi Amerta Desa Sangsit menerapkan prinsip dengan menjalankan kearifan lokal yang disebut dengan prinsip "Pang Pade Payu".

Berdasarkan atas latar belakang yang telah dipaparkan diatas, adapun rumusan masalah yang dapat disusun peneliti, yakni: (1) Bagaimana sistem pengendalian internal yang diterapkan Badan Usaha Milik Desa Sidi Amerta Sangsit dalam menghadapi kredit macet, dan (2) Bagaimana penerapan prinsip "pang pade payu" untuk menyelesaikan kredit macet pada BUMDes Sidi Amerta

\section{Metode}

Penelitian ini menggunakan penelitian deskritif dengan pendekatan kualitatif. Menurut Arikunto (2016: 129) Penelitian deskriptif merupakan penelitian yang menuturkan dan menafsirkan data yang ada misalnya situasi yang dialami, suatu hubungan kegiatan, pandangan, pengaruh yang sedang diteliti, pertentangan yang sedang meruncing dan sebagainya. Sedangkan pendekatan kualitatif menurut Bogdan dan Taylor (dalam Moeleong, 2000) adalah prosedur penelitian yang menghasilkan data deskritif berupa kata-kata tertulis atau lisan dari orang-orang dan perilaku yang diamati. Penelitian ini mendeskrifsikan faktafakta terkait dengan sistem pengendalian iternal dengan prinsip "pang pade payu" yang diterapkan BUMDes Sidi Amerta Desa Sangsit. 
Jenis data yang digunakan dalam penelitian ini adalah data kualitatif. Sumber data dari penelitian ini menggunakan data primer dan data sekunder. Sedangkan untuk teknik pengumpulan data yang digunakan dalam penelitian ini melalui metode observasi, metode wawancara, dan dengan metode dokumentasi. Kemudian data dianalisis dengan menggunakan serangkaian tahap-tahap yaitu reduksi data, penyajian data, dan penarikan kesimpulan.

\section{Hasil dan Pembahasan}

\section{Gambaran Umum Badan Usaha Milik Desa (BUMDES) Sidi Amerta}

Badan Usaha Milik Desa (BUMDes) Sidi Amerta merupakan usaha formal yang dikelola oleh Pemerintah dan berbadan hukum, hal ini tidak terlepas dari keberadaan program Gerbang Sadu Mandara (GSM) dari Pemerintah Provinsi Bali. Badan Usaha Milik Desa (BUMDes) Sidi Amerta dirikan dengan Peraturan Desa Sangsit Nomor : 04 Tahun 2014 yang ditetapkan pada tanggal 15 Januari 2014. Badan Usaha Milik Desa (BUMDes) Sidi Amerta pada awalnya bersumber dari Program Gerakan Membangun Desa (Gerbangsadu) Provinsi Bali sebesar Rp. 1.020.000.000 (satu milyar dua puluh juta rupiah). Namun biaya untuk operasional dari BUMDes Sidi Amerta sebesar Rp. 934.300.000, sisanya yaitu Rp 85.700.000 digunakan untuk biaya gedung BUMDes Sidi Amerta. BUMDes Sidi Amerta memiliki beberapa unit usaha antara lain : (1) Unit Usaha Pelayanan Umum, (2) Unit Usaha Sewa \& Perantara, (3) Unit Usaha Bisnis \& Keuangan, (4) Unit Usaha Bisnis Produksi Dan Kelautan, (5) Unit Usaha Wisata dan usaha bersama.

Pada saat pencairan dana timbulnya kelalaian sistem pengendalian dalam pemberian kredit yang dilakukan oleh Bapak Swastika selaku mantan ketua BUMDes Sidi Amerta, dengan memberikan kredit kepada nasabah RTM tanpa jaminan atau agunan sebesar $80 \%$ lebih besar dari pada pemberian kredit yang diterima oleh nasabah yang menggunakan jaminan atau agunan sebesar $20 \%$, hal ini membuat semakin menumpuknya para nasabah RTM tanpa agunan untuk meminjam pinjaman kepada BUMDes Sidi Amerta karena kemudahan dalam meminjam pinjaman kredit. Seperti halnya yang dikatakan oleh Ketua BUMdes Sidi Amerta (Komang Agus Karmajaya,48) sebagai berikut:

"Pidan ketua SP ne maluan jak Ketua BUMDes maluan lebih bek ane nerime (Pada saat itu Ketua Simpan Pinjam dan Mantan Ketua BUmdes terdahulu lebih banyak menerima) nasabah tanpa jaminan secara terus-menerus sampek menumpuk dibandingkan nasabah yang menggunakan jaminan hanya kisaran $20 \%$ den nu ngidaang itung angon jari-jari ( masih bisa dihitung dengan jari-jari), untuk jani nu memikirkan masalah ne nike adi sampek bek kene mare liu ngerepak...(Untuk sekarang ini masih memikirkan masalahnya kenapa sampai banyak seperti ini yang membuat semua harus bergerak cepat untuk menangani ini). Yen jani be meganti ketua SP ne, jani ane nganti madan Aryani Bijayanti mare-mare ne ye masuk di BUMDEs ne (Untuk sekarang sudah diganti Ketua Simpan Pinjam, dan sekarang bernama Aryani Bijayanti yang baru-baru ini bekerja di BUMDes Sidi Amerta)"

Selain hal tersebut mantan ketua BUMDes Sidi Amerta melakukan tindakan korupsi yang membuat unit usaha peternakan pada BUMDes Sidi Amerta menjadi tidak beroperasi karena hal tersebut. Lemahnya sistem pengendalian internal juga disebabkan oleh pengurus yang kurang mempunyai pengetahuan di bidang akuntansi dan hanya berlatar belakang pendidikan SMA.

Kebijakan yang dibuat oleh pengurus BUMDes Sidi Amerta dan Pemerintah Desa yaitu Sanksi yang dilakukan oeh pengurus BUMDes Sidi Amerta tidak akan dilayani administrasi atau surat-menyurat di Kantor Kepala Desa, dari sanksi tersebut tidak membuat kurangnya para nasabah kredit macet, hal ini pihak pengurus BUMDes Sidi Amerta melakukan tindakan penerapan dengan menerapkan Prinsip "pang pade payu" yang dimaksud dalam hal ini yaitu nasabah diperbolehkan hanya membayar bunga tanpa membayar pokok angsuran selama 3 bulan berturut-turut tetapi pinjaman lunas dalam jangka waktu yang sudah ditetapkan. Dalam hal ini pengelolaan yang dilakukan pihak pengurus BUMDes dengan tindakan semangat kekeluargaan dan kegotongroyongan serta untuk 
memberikan kenyaman satu sama lain dari pihak pengurus serta bagi para nasabah Badan Usaha Milik Desa (BUMDes) Sidi Amerta

\section{Sistem Pengendalian Internal Pada BUMDes Sidi Amerta}

Penerapan keefektifan pengendalian internal d BUMDes Sidi Amerta dapat dilihat dari : (1) lingkungan Pengendalian yang dibuktikan dengan ketaatan aturan para pengurus BUMDes pada standar yang berlaku dan etika dalam bertingkah laku yang sopan pada nasabah; komitmen individu yaitu kesiapan pengurus menjalankan tugas dan tanggung jawab sebagai pengurus BUMDes cukup baik; BUMDes Sidi Amerta memiliki Ketua yang mengawasi jalannya pengelolaan dan juga melakukan audit bukti transaksi secara rutin; Manajemen BUMDes telah diatur dan dilaksanakan sesuati dengan aturan yang berlaku; Struktur organisasi yang terdapat pada BUMDes Sidi Amerta sudah membentuk struktur organisasi yang baik dan memiliki tugas dan tanggungjawab masing-masing; Praktik dari sumber daya BUMDes yang mempunyai sifat jujur dan keterampilan yang baik dalam melayani masyarakat dengan baik; (2) Penilaian Risiko (Risk Assessment) Dari pengujian faktor eksternal, pembaruan kurang optimal pada sistem informasi dan komunikasi karena BUMDes Sidi Amerta hanya berfokus pada resiko kesalahan perangkat lunak. Dan pengujian terhadap faktor internal di BUMDes yaitu adanya personel baru, dimana karyawan atau pengurus yang baru kurang mempunyai pengetahuan dan kemampuan di bidangnya; (3) Aktivitas Pengendalian (Control Activities), BUMDes telah menjalankan otorisasi dengan baik oleh Ketua BUMDes; memiliki Dokumen dan catatan berupa kwintansi, bukti fisik sewamenyewa, dan lain-lain, Ketua dan Bendahara BUMDes saling melakukan pengecekan independen dengan cara menjalankan prosedur verifikasi data, Ketua BUMDes harus menjamin tidak adanya perangkapan tugas, BUMDes menyediakan ruang penyimpanan untuk dokumen penting dan kendali pengamanan kompeten, memantau pencapaian kinerja BUMDes secara rutin. (4) Sistem Informasi di BUMDes sudah memadai karena sudah adanya rancangan sistem informasi akuntansi di dalam Laporan Pertanggungjwaban Akhir Tahun. Laporan Pertanggungjwaban Akhir Tahun, dan juga Bukti Transaksi yang dikeluarkan oleh BUMDes yang bersangkutan; (5) Pemantauan berkelanjutan diselenggarakan melalui kegiatan pengelolaan rutin setiap satu bulan sekali dilakukan oleh Pengawas BUMDes. Dan evaluasi terpisah diselenggarakan melalui review dan pengujian efektivitas sistem pengendalian internal yang dapat dilakukan oleh pengawas BUMDes

\section{Sistem Pemberian Kredit Pada BUMDes Sidi Amerta}

Sistem pemberian kredit pada BUMDes Sidi Amerta terdapat dua kelompok diantaraya: kredit RTM tanpa jaminan dan kredit yang menggunakan jaminan. Prosedur dalam pemberian kredit RTM tanpa jaminan pada BUMDes Sidi Amerta, yaitu Calon debitur mengisi formulir Surat Permohonan Kredit (SPK) dan mengajukann permohonan kredit, lalu dicek kembali oleh bagian sekretaris dan Ketua pada Usaha Simpan Pinjam. Lalu Karyawan bagian Usaha Simpan Pinjam akan segera mengisi kolom bagian rekomendasi kredit, Ketua Bumdes akan memberikan keputusan mengenai surat permohonan kredit disetuju atau tidak. Calon debitur yang pantas atau layak mendapatkan pinjaman akan segera mengisi Surat Pernyataan Hutang (SPH) dan Surat Permohonan Kredit (SPK) akan berisikan tanda tangan persetujuan suami/istri yang bersangkutan. Lalu saat pencairan dana, Bendahara akan segera mengeluarkan kwitansi pengeluaran kredit sebesar jumlah kredit. Pada saat pembayaran, debitur akan mendatangi kantor BUMDes Sidi Amerta dengan membawa Kartu Angsuran. Sedangkan Pada Prosedur pemberian kredit yang menggunakan jaminan pada BUMDes Sidi Amerta hampir sama dengan prosedur pemberian kredit non jaminan, namun adanya barang jaminan dilakukan sesuai dengan ketentuan yang berlaku, saat kredit belum bisa dilunasi maka barang jaminan yang diserahkan tersebut dilarang untuk dijual.

\section{Peranan Prinsip "Pang Pade Payu” Dalam Menyelesaikan Kredit Macet Pada BUMDes Sidi Amerta}


Penyelesaian kredit macet pada BUMDes Sidi Amerta sebelumnya sudah menerapkan Sanksi Administrasi kepada nasabah yang belum membayar kewajibannya yaitu dengan tidak dilayani surat-menyurat di Kantor Kepala Desa. Namun hal ini, belum cukup untuk menangani masalah kredit macet pada BUMDes Sidi Amerta. Sehingga dilakukan strategi dalam menangani kredit macet dengan berlandaskan kekeluargaan ataupun kegotongroyongan dengan cara musyawarah sehingga nantinya tidak ada pihak yang akan menguntungkan ataupun merugikan sebelah pihak. Dari penyelesaian masalah tersebut dikenal dengan istilah win-win solution. Di bali, dalam penyelesainnya masalah model ini dijumpai hal yang serupa yang sering di dijumpai dengan kearifan lokal yaitu prinsip "pang pade payu". Penerapan prinsip "pang pade payu" pada BUMDes Sidi Amerta diakukan dengan cara keluaragaan yang dimaksud yaitu melakukan pendekatan secara langsung dengan masyarakat Desa Sangsit yang menungak kewajibannya. Dalam hal ini, pihak pengurus BUMDes Sidi Amerta akan menanyakan apa yang menyebabkan nasabah tidak mambayar kewajibannya. Selanjutnya pengurus BUMDes Sidi Amerta akan memikirkan apakah misalnya kalau nasabah masih mempunyai niat baik untuk membayar kredit tetapi masih dalam kesulitas ekonomi ataupun keuangan, maka pihak pengurus BUMDes Sidi Amerta akan memberikan perpanjangan waktu kepada nasabah yang ingin membayar kewajibannya tersebut. Namun, jika perpanjangan waktu yang diberikan yang telah jatuh tempo masih tetap belum bisa membayar kewajibannya maka pihak pengurus BUMDes Sidi Amerta dan nasabah tersebut akan segera melakukan negosiasi. Negosiasi ini biasanya diambil dengan keputusan dengan cara meminta pembayaran bunganya saja tanpa terlebih dahulu membayar pokonya. Selanjutnya, selama etikad baik dari nasabah masih terus baik dengan meminta perpanjangan jangka waktu maka pihak pengurus akan meminta biaya administrasi dan materai seperti untuk pengajuan kredit baru. Hal ini disampaikan oleh (Bapak Agus Karmajaya,48) selaku Ketua BUMDes Sidi Amerta:

"Prinsip pang pade payu yang diterapkan BUMDes nike (ini) selama masih ada itikad baik uli (dari) nasabah pasti tiang akan ngelah rasa kepercayaanlah dengan ngalih jalan keluar ane lebih bisa bijak (pasti saya akan mempunyai rasa kepercayaan dengan mecari jalan keluar yang lebih bijak). Amen ane sing angon jaminan pang ngidaang sing memaksekan pang nyemak barang anake ( kalau misalnya tidak menggunakan jaminan agar naninya tidak memaksakan untuk mengambil hak milik barang mereka) tapi nah... tetep lah mayah bungane den (tetapi agar tetap membayar bunga nya saja). Pang pade payune nike maksudne kan pang ngidaang kredit nike lebih bisa diperpanjang pang sing memaksekan pang harus prejanian yen jani yah jani (Prinsip "pang pade payu" ini mempunyai arti agar nantinya kredit lebih bisa diperpanjang agar tidak memaksakan yang harusnya sekarang ya sekarang), yen dini sing.... Nu ngidaang diperpanjang dengan bahwa dia itu kredit baru lagi nah palingan kene biaya admistrasi (Kalau disini tidak, di BUMDes masih bisa diperpanjang dengan bahwa nasabah tersebut diasumsikan dia kredit baru lagi dan dikenai biaya admistrasi) jak meterai neto den dan sebagainya pang sing memberatkan masyarakat di desa sangsit ini ( dan materai ini saja dan lain sebagianya agar nantinya tidak memberatkan)"

Uraian diatas sudah dijelaskan sebelumnya, penerapan prinsip "pang pade payu" pada BUMDes Sidi Amerta yaitu dengan cara memberikan jangka waktu yang diperpanjang maksudnya yaitu toleransi kepada nasabah yang masih mempunyai etikad baik kepada para pengurus BUMDes Sidi Amerta untuk membayar kewajibannya. Dalam hal ini, juga disampaikan oleh nasabah yang pernah meminjam kredit pada BUMDes Sidi Amerta yang bernama (Ibu Ginada, 45), mengungkapkan bahwa :

"tiang dadi nasabah di BUMDes taen sing mayah 3 bulan (saya menjadi nasabah di BUMDes pernah tidak membayar selama 3 bulan), sing engekenange je tiang jak penguruse ( tidak di apa-apakan saya oleh pengurus), nak alie den umae ajakine ngomong palingan takonang adi sing ngidaang mayah ne nak be telah jangka waktune buk (cumin di cari saja kerumah dengan diberikan pertanyaan kenapa tidak bisa membayar padahal sudah jangka waktunya buk), terus nto bange je perpanjangan waktu nike ( selanjutnya diberikan 
perpanjangan waktu), nah...sai lah teke ane sai teke ento ketua BUMDes ne metakonmetakon ( kemudian yang paling sering datang yaitu Ketua BUMDes yang sering bertanya)"

Prinsip "pang pade payu" yang diterapkan BUMDes Sidi Amerta yaitu dengan cara pendekatan secara langsung dengan para nasabahnya agar nantinya bisa membayar kewajibannya tersebut. Akan tetapi, dengan catata nasabah tersebut masih mempunyai etikad yang baik untuk meminta perpanjangan jangka waktu. Dan hal ini, juga diingatkan bahwa tetap membayar bunganya saja tanpa membayar pokoknya terdahulu. Dan pihak pengurus BUMDes melayani masyarakatnya dengan sistem kekeluargaan yang mebuat para masyarakat di Desa Sangsit menjadi nyaman karena hal tersebut.

Dalam hal ini, penerapan prinsip " pang pade payu” yang diterapkan oleh BUMDes Sidi Amerta menerapkan konsep kekeluargaan maksudnya yaitu dalam penyelesain kredit pihak pengurus BUMDes Sidi Amerta dan para nasabah selalu menerapkan prinsip "pang pade payu"dengan memberikan toleransi kepada nasabah yang mempunyai etikad baik. Sehingga, para nasabah pada BUMDes Sidi Amerta merasa diuntungkan dan merasa nyaman. Meskipun, ketika diperpanjang jangka waktunya akan dikenakan biaya administrasi serta meterai, masyarakat Desa Sangsit tidak merasa terbebani karena hal tersebut, melainkan bisa meringankan masalahnya untuk membayar kewajibannya tersebut. Penerapan dari prinsip "pang pade payu" ini sangat memiliki keadilan. Dan dari pihak BUMDes Sidi Amerta juga akan merasa diuntungkan karena kreditnya terselamatkan sehingga sedikit kurangnya timbulnya kredit macet yang sampai membuat Badan Usaha Milik Desa tidak sehat atau kurang efektif tapi masih tetap bisa beroperasi.

Sebelumnya, sanksi yang diterapkan oleh pihak BUMDes Sidi Amerta sudah diterapkan sebelum memulainya prinsip "pang pade payu" namun tidak membuat efek jera bagi para nasabah yang belum membayar kewajibannya, sanksi yang diterapkan oleh Ketua BUMDes bersama Kepala Desa apabila nasabah tidak mambayar kewajibannya yaitu tidak mendapat pelayanan administrasi di Kantor Kepala Desa seperti pelayanan dalam mengurus adminisitrasi penduduk yang meliputi dokumen kependudukan (Kartu Keluarga,Kartu Tanda Penduduk, KTP, Akta Pencatatan Sipildan lain sebagainya). Dan Surat Ketengan Kepependudukan yang meliputi : Surat Keterangan Pindah, Surat Keterangan Tidak Mampu dan lain sebagainya). Hal ini sesuai dengan kutipan wawancara dengan (Bapak Agus Karmajaya,48) selaku Ketua BUMDes Sidi Amerta:

"Tiang sareng (Saya bersama) Kepala Desa bekerjasama dan sepakat untuk mengeluarkan sanksi dengan tidak mendapat pelayanan administrasi atau surat-menyurat di Kantor Kepala Desa ane (untuk) nasabah yang tidak membayar kewajibanne nike (kewajibannya tersebut). $\mathrm{Ne}$ be atas ( Ini sudah atas) persetujuan dari pihak nasabah masi be (sudah) melakukan perjanjian tertulis pas ye lakar ngidih ( pada saat debitur akan meminta) formulir Surat Permohonan Kredit"

Penerapan Sanksi Administrasi di BUMDes Sidi Amerta yang dimulai pada tahun 2015 sejak dijalankan tidak mengurangi masalah kredit macet di BUMDes Sidi Amerta, Hal ini diungkapkan langsung oleh Bapak Agus Karmajaya selaku Ketua BUMDes Sidi Amerta yang menyatakan bahwa:

"Awal tahun 2015 be (sudah) menerapkan sanksi administrasi bagi nasabah, tapi nu den ade (masih aja ada) masalah kredit macet ne (ini) semakin menumpuk, nah.. ade nasabah ne mekeneh (ada yang berpikir), nah.. sing engken be men kudiang men (mau gimana lagi). Sing ade pis angon mayah ( tidak ada uang untuk membayar), dadine bagi nasabahne be sing peduli ( jadinya bagi nasabah tidak peduli) untuk sanksi kedepanne. Nah.. yen be kene keweh ngorain ( kalau sudah seperti ini susah diberitahu), makane rage ne (saya) sebagai pengurus segera melakukan antisipasi untuk mencegah ane lebih buruk (yang). makane tiang sareng pengurus langsung gercep langsung tuun kelapangan langsung nekain nasabah ane bermasalah (jadinya saya bersama pengurus langsung secepatnya turun kelapangan menemui nasabah yang bermasalah) dalam melakukan pembayarannya, trus tiang berunding be jak nasabahne terkait jak masalah nike ( selanjutnya saya berdiskusi dengan nasabah terkait dengan masalah itu), nah..sebenehne penerapan sanksi neto tetap 
berjalan ampek jani hanya saja karna kredit macet nu tileh mengalami penumpukan ( dan sebenarnya penerapan sanksi tersebut tetap berjalan sampai sekarang hanya saja kredit macet masih saja mengalami penumpukan). dadine nah... sing je penerapan neto den kita angon Patokan pang ngae para nasabah nyak mayah kewajibanne ( oleh karena itu tidak hanya penerapan itu saja kita utamakan agar para nasabah mau membayar kewajibannya) tapi mencari jalan keluar yang lain dengan cara memunculkan kearifan lokal yaitu dengan "prinsip pang pade payu" agar nantinya tiang sareng (saya bersama) pengurus yang lain mencarikan solusi atas permasalahan ne manten (ini)"

Dari pernyataan diatas, maka prinsip "pang pade payu" memiliki peran penting untuk mengurangi masalah kredit macet di BUMDes Sidi Amerta dengan cara melakukan pendekatan langsung dengan para nasabah agar nantinya masalah yang dihadapi nasabah bisa di selesaikan dengan baik oleh pihak pengurus BUMDes Sidi Amerta dengan nasabahnya secara langsung.

Kebijakan Prinsip "pang pade payu" ini lah penting dan memiliki manfaat yang baik bagi para nasabah dan juga pengurus BUMDes Sidi Amerta untuk mengatasi kredit macet selain penerapan sanksi dinas tersebut. Maka, dengan menggunakan prinsip "pang pade payu" di BUMDes Sidi Amerta telah mecapai keadilan sesuai dengan arti prinsip "pang pade payu" itu sendiri yang merupakan model penyelesaian dalam suatu masalah dengan tidak saling menguntungkan atau merugikan salah satu pihak. Sehingga, BUMDes Sidi Amerta dapat diselamatkan agar nantinya bisa mengurangi kredit macet tersebut sampai membuat BUMDes Sidi Amerta menjadi Lembaga Keuangan yang dikategorikan sehat.

\section{Simpulan dan Saran}

Dari hasil penelitian, maka dapat ditarik beberapa kesimpulan yang dapat menjawab permasalahan yang terdapat dipenelitian ini yaitu; pertama, Sistem Pengendalian Internal di BUMDes Sidi Amerta sudah tergolong cukup bagus karena BUMDes Sidi Amerta memiliki struktur organisasi, otorisasi dokumen dan catatan oleh Ketua, dan pemisahan tugas yang jelas, hanya saja sumber daya manusia dalam merekrut karyawan yang kurang seperti tidak memiliki pengetahuan di bidang akuntansi dan latar belakang pendidikan beberapa pengurus BUMDes hanya pada tingkat SMA. Kedua, Prinsip "pang pade payu" di BUMDes Sidi Amerta berawal dari kurang efektifnya Sanksi Administrasi dalam mengurangi masalah kredit macet. Penerapan Sanksi ini yang ditujukan pada nasabah kredit macet yang dilakukan dengan tidak dilayani surat-menyurat administrasi di Kantor Kepala Desa. Maka, muncul prinsip "pang pade payu" yang merupakan strategi dalam menangani nasabah kredit macet yang didukung oleh semua pihak baik nasabah maupun pengurus BUMDes karena prinsip ini berlandaskan kekeluaragaan yang sifatnya tidak memaksa dan juga baik untuk operasional BUMDes kedepannya.

Berdasarkan penelitian tersebut adapun saran yang dapat diberikan oleh peneliti sebagai berikut, pertama, Bagi pihak BUMDes Sidi Amerta diharapkan pada Prosedur Surat Permohonan Kredit dengan berisikan tanda tangan Kelian Desa Pakraman tetap dijalankan dengan baik agar nantinya calon nasabah yang akan meminjam dana pada BUMDes Sidi Amerta tetap mengikuti persyaratan yang sudah tercantum di Surat Permohona Kredit tersebut. Dan lebih bisa selektif dalam pemberian kredit sesuai dengan kemampuan nasabah pencari kredit tersebut, dan, kedua, bagi pihak peneliti diharapkan untuk melakukan penelitian dengan ruang lingkup yang lebih luas sehingga dapat dibandingkan serta melakukan penelitian mengenai kelebihan dan kelemahan prinsip "pang pade payu"pada BUMDes Sidi Amerta agar nantinya bisa mengetahui apakah efektif atau tidaknya melaksanakan prinsip tersebut untuk nantinya dapat menyelesaikan kredit macet tersebut.

\section{Daftar Pustaka}

Anonim. 2013. Dengan prinsip pang pada payu, penyelesaian sengketa atau masalah dilandasi konsep kedamaian. Pang pada payu berakar pada nilai-nilai, yang diakses pada: www.balisaja.com/2013/07/pang-pada-payu-prinsip-win-winsolution.html 1 april2020. 
Arikunto, S. (2016). Dasar-dasar Evaluasi Pendidikan. Jakarta: Bumi Aksara.

Ayuni, Sri. (2019). Strategi Kredit Macet Pang Pade Payu pada Lembaga Perkreditan Desa di Kabupaten Buleleng. Sintesa Prosiding 2019.

Indra Bastian. 2011. Audit Sektor Publik. Jakarta : Salemba Empat.

Ismail. 2013. Manajemen Perbankan. Jakarta: Prenadamedia

Kasmir. 2012. Bank dan Lembaga Keuangan Lainnya. Jakarta: PT Raja Grafindo Persada.

Krismiaji, 2010. Sistem Informasi Akuntansi. Yogyakarta: UPP AMP YKPN.

Kurniawan, Agung. 2005. Transformasi Pelayanan Publik. Yogyakarta, Pembaruan.

Moleong, Lexy J. Metodologi Penelitian Kualitatif, (Bandung : PT Remaja Rosda Karya, 2000)

Mulyadi. (2014). Auditing. Jakarta: Salemba Empat.

Mulyadi. 2010. Sistem Akuntansi, Edisi ke-3, Cetakan ke-5. Penerbit Salemba Empat, Jakarta.

Peraturan Gubernur Bali (Pergub Bali) No 52 Tahun 2013 Tentang Program Gerbang Sadu Mandara.

Peraturan Menteri Dalam Negeri Nomor 39 Tahun 2010 tentang Badan Usaha Milik Desa.

Peraturan Menteri Desa, Pembangunan Daerah Tertinggal, Dan Transmigrasi Republik Indonesia Nomor 4 Tahun 2015 Tentang Pendirian, Pengurusan Dan Pengelolaan, Dan Pembubaran Badan Usaha Milik Desa.

Peraturan Pemerintah No 43 Tahun 2014 tentang desa.

Republik Indonesia. 2014. Undang-Undang Nomor 6 Tahun 2014 tentang Desa.

Rismawati. (2018). Peranan Badan Usaha Milik Desa (Bumdes) Perwitasari Dalam Upaya Meningkatkan Perekonomian Masyarakat Minapolitan Desa Tambaksari Kecamatan Rowosari Kabupaten Kendal. Semarang: Skripsi Universita Negeri Walisongo (tidak diterbitka).

Sugiyono. (2010). Metode Observasi Dan Wawancara Dalam Penelitian. Jakarta

Sujaya. 2013. "Pang Pada Payu", Prinsip "Win-win Solution"Bali. Dalam http://www.balisaja.com/2013/07/pang-pada-payu-prinsip-win-win-solution.html, diunduh pada tanggal 19 Maret 2020 